\title{
Penerapan Layanan Penguasaan Konten Untuk Mengurangi Prokrastinasi Akademik Siswa
}

\author{
Muhammad Alfi Syahrin'1, Taufik², Frischa Meivilona Yendi' ${ }^{3}$, Verlanda Yuca ${ }^{4}$ \\ ${ }^{1234}$ Universitas Negeri Padang \\ *) Correspondence author, e-mail: alfisyahrin2612@gmail.com
}

\begin{abstract}
Prokrastinasi akademik rentan terjadi di dunia pendidikan. Prokrastinasi akademik ini banyak dilakukan oleh Siswa di sekolah. Siswa cenderung senang menunda-nunda dalam mengerjakan tugas sekolah dan lebih banyak melakukan kegiatan lainnya. Beberapa faktor dari prokrastinasi akademik seperti kecanduan dalam bermain game online, kemudian karena adanya keyakinan tidak rasional yang dimiliki oleh Siswa, Keyakinan tidak rasional tersebut dapat disebabkan oleh kesalahan dalam mempersepsikan tugas sekolah. Kesalahan persepsi ini seperti menganggap tugas sekolah sulit untuk dikerjakan atau akan mendapatkan nilai yang cukup asalkan mengumpulkan tugas. Prokrastinasi akademik ini menyebabkan Siswa melakukan penundaan dalam mengerjakan tugas sehingga jika tugas bisa selesai, maka hasil dari tugas tersebut tidak maksimal atau tidak memuaskan. Prokrastinasi akademik dapat dikurangi melalui Layanan Bimbingan dan Konseling. Guru BK dapat memberikan berbagai jenis layanan salah satunya layanan penguasaan konten. Melalui layanan penguasaan konten ini Siswa diberikan materi keterampilan dalam mengatur waktu terutama mengatur waktu dalam belajar, sehingga diharapkan Siswa dapat mengerjakan tugas-tugas sekolah dengan baik, maksimal dan juga dapat dikumpulkan pada waktu yang tepat. Namun, Hal demikian tidak akan lepas dari Siswa itu sendiri yang ingin berubah secara pribadi ke arah yang lebih baik
\end{abstract}

Keywords: Layanan Penguasaan Konten, Prokrastinasi Akademik Siswa

Article History: Received on 25/05/2019; Revised on 25/06/2019; Accepted on 21/07/2019; Published Online: 30/07/2019.

(c) (1) This is an open access article distributed under the Creative Commons Attribution License, which permits unrestricted use,
distribution, and reproduction in any medium, provided the original work is properly cited. (C2019 by author.

Pendidikan merupakan suatu aspek yang tidak dapat dipisahkan dari kehidupan Individu, pada dasarnya Individu memiliki kecenderungan dalam menempuh pendidikan baik pada lembaga pendidikan formal, nonformal, dan informal. Dari dulu hingga saat ini bahkan perkembangan dunia kedepannya akan membutuhkan pendidikan sebagai agent untuk perubahan. Dari tahun ke tahun, sistem pendidikan selalu mengalami perubahan dengan harapan mutu pendidikan terutama di Indonesia dapat berubah ke arah yang lebih baik. Undang-Undang Nomor 20 tahun 2003 tentang Sistem Pendidikan Nasional Pasal 1 Ayat 1 menyebutkan bahwa "Pendidikan adalah usaha sadar dan terencana untuk mewujudkan suasana belajar dan proses pembelajaran agar peserta didik secara aktif mengembangkan potensi dirinya untuk memiliki 
kekuatan spiritual keagamaan, pengendalian diri, kepribadian, kecerdasan, akhlak mulia, serta keterampilan yang diperlukan dirinya, masyarakat, bangsa dan negara".

Untuk mencapai tujuan yang sudah tertuang di dalam Undang-Undang tersebut, tentunya harus ada proses belajar yang baik dan sesuai dengan prosedur yang ditentukan, baik dari satuan pendidikan, Guru tidak terkecuali Siswa sendiri. Siswa yang aktif juga menunjang terlaksananya sistem pendidikan itu sendiri.

Pada saat ini, dengan perkembangan zaman dan juga perkembangan teknologi menyebabkan adanya Individu yang lalai dalam mengerjakan tugas-tugasnya baik dalam lingkungan keluarga, sosial, maupun dalam lingkungan pendidikan sendiri. Lingkungan pendidikan ini tidak terkecuali pada Siswa sendiri. Dalam mengerjakan tugas-tugas sekolah, ada Siswa yang menunda-nunda dalam pengerjaan tugas tersebut. Hal ini banyak faktor yang mempengaruhi terjadinya penundaan tugas tersebut, salah satunya karena pergaulan dengan sesama Siswa seperti sama-sama bermain game online, kemudian motivasi belajar yang kurang. Penundaan pengerjaan tugas-tugas ini disebut juga dengan Prokrastinasi Akademik. Menurut Wolter (Muyana \& Dahlan, 2018) prokrastinasi akademik merupakan kegagalan dalam mengerjakan tugas akademik dalam kerangka waktu yang diinginkan atau menunda mengerjakan tugas sampai saat-saat terakhir. Dengan adanya perilaku prokrastinasi akademik tersebut, dapat mengakibatkan Siswa menjadi tidak produktif dalam proses belajarnya. Senecal, Koestner \& Vallerand (Gohil, 2014) mendefinisikan "Academic procrastination can be undestood as knowing that one is supposed to, and perhaps even wanting to, complete an academic task but failing to perform the activity whitin the expected or desired time frame". Maksudnya adalah prokrastinasi akademik merupakan penundaan pekerjaan tugas akademik yang dilakukan secara berulang-ulang dan tidak menghasilkan pekerjaan yang maksimal, sehingga pada akhirnya akan menimulkan kecemasan bagi Individu.

Berdasarkan permasalahan tersebut, Guru BK memiliki peran penting dalam membimbing Siswa dalam proses belajarnya. Guru BK dapat menerapkan berbagai layanan yang tepat dalam mengentaskan prokrastinasi akademik Siswa tersebut. salah satu Layanan yang dapat diberikan adalah Layanan Penguasaan Konten. Layanan Penguasaan Konten merupakan salah satu jenis layanan Bimbingan dan Konseling untuk membantu Individu atau kelompok untuk menguasai kemampuan atau kompetensi tertentu melalui kegiatan belajar (Prayitno, 2004). Dengan penguasaan konten bagi Siswa yang cenderung melakukan prokrastinasi akademik bertujuan untuk mengubah perilaku Siswa agar dapat mengubah kebiasaan menunda-nunda terutama dalam pengerjaan tugas-tugas sekolah. Keterampilan yang dapat dilakukan yaitu keterampilan mengatur waktu dengan baik agar dapat menyelesaikan tugas dengan baik dan tepat waktu.

\section{Prokrastinasi Akademik}

Dalam konteks akademik, penundaan tersebut disebut dengan Prokrastinasi akademik. Penundaan dilakukan secara berulang-ulang daan dilakukan dengan sengaja. Biasanya seseorang yang melakukan prokrastinasi akademik menunda pengerjaan tugasnya, walaupun ia mengetahui dan memahami tugas yang akan dikerjakan. Prokrastinasi akademik ini sebagai penundaan terhadap tugas-tugas akademik seperti 
menulis makalah, menyelesaikan tugas resume, dan menunda untuk mempersiapkan ujian.

Rumiani (2006) menyatakan kecenderungan untuk menunda dalam melaksanakan suatu aktivitas disebut dengan prokrastinasi. Basri (2017) mengemukakan bahwa Prokrastinasi akademik adalah menunda-nunda pekerjaan dibidang akademik. Senada dengan pendapat tersebut, Husetiya (Suharsono, 2013) mengartikan prokrastinasi akademik merupakan penundaan yang dilakukan secara sengaja dan berulang-ulang dalam menyelesaikan suatu tugas atau pekerjaan, baik memulai maupun menyelesaikan tugas yang berhubungan dengan bidang akademik.

Kemudian sejalan dengan pendapat tersebut, Balkis \& Duru (2009) menyatakan bahwa "Procrastination is defined as a behavior in which an individual leaves a feasible, important deed planned beforehand to another time without any sensible reason". Maksudnya yaitu prokrastinasi merupakan perilaku individu yang meninggalkan kegiatan penting yang bisa dilakukan dan telah direncanakan sebelumnya tanpa alasan yang dapat diterima oleh akal manusia.

Miligram (Ghufron \& Risnawita, 2010) memberikan gambaran prokrastinasi ke dalam empat perilaku spesifik yang meliputi: (1) suatu perilaku yang melibatkan unsur penundaan, baik untuk memulai maupun menyelesaikan suatu tugas atau aktivitas; (2) menghasilkan akibat-akibat lain yang lebih jauh misalnya keterlambatan menyelesaikan tugas maupun kegagalan dalam mengerjakan tugas; (3) melibatkan suatu tugas yang dipersepsikan oleh prokrastinator (pelaku prokrastinasi) sebagai suatu tugas yang penting, seperti misalnya tugas sekolah; dan (4) menghasilkan keadaan emosional yang tidak menyenangkan seperti perasaan cemas, bersalah, marah dan panik.

Kemudian, dalam perilaku prokrastinasi akademik tentunya ada prokrastinator yaitu Individu yang melakukan prokrastinasi. Wolters (Fauziah, 2015) mengemukakan bahwa Prokrastinator (Individu yang melakukan Prokrastinasi) sebenarnya sadar bahwa dirinya menghadapi tugas-tugas yang penting dan bermanfaat bagi dirinya sebagai tugas pokok yang seharusnya dikerjakan, namun Individu dengan sengaja menunda-nunda pekerjaannya secara berulang-ulang atau kompulsif.

Solomon \& Rothblum (1984) mengemukakan bahwa Prokrastinasi akademik terjadi karena adanya keyakinan tidak rasional yang dimiliki oleh siswa. Keyakinan tidak rasional tersebut dapat disebabkan oleh kesalahan dalam mempersepsikan tugas sekolah, merupakan motif siswa memandang tugas sebagai sesuatu yang berat dan tidak menyenangkan (aversineves of the task dan fear of failure), yaitu ketakutan yang berlebihan untuk gagal, siswa menunda-nunda mengerjakan tugas sekolahnya karena takut jika gagal menyelesaikannya sehingga akan mendatangkan penilaian yang negatif akan kemampuannya. Akibatnya seseorang menunda-nunda untuk mengerjakan tugas yang dihadapinya.

Ferrari (Suharsono, 2013) mengemukakan bahwa Munculnya perilaku prokrastinasi akademik ini ditunjang oleh beberapa faktor yang kondusif untuk menjadi katalisator munculnya perilaku prokrastinasi akademik pada seseorang yaitu faktor internal, yaitu faktor yang ada dalam diri individu yang meliputi faktor fisik dan psikologis dan faktor 
eksternal berupa faktor di luar diri individu berupa gaya pengasuhan dan kondisi lingkungan yang linier.

Solomon \& Rothblum (1984) mengemukakan bahwa indikator dari prokrastinasi akademik dalam proses belajar Siswa terdapat 6 (enam) aspek, yaitu:

1. Terlambatnya dalam mengerjakan tugas

2. Menunda belajar saat menghadapi ujian

3. Menunda kegiatan membaca

4. Penundaan kinerja tugas administratif

5. Menunda untuk menghadiri tatap muka

6. Penundaan kinerja akademik secara keseluruhan

Penundaan terhubung dengan perilaku dan hasil negatif, seperti terlambat mengumpulkan tugas, terlambat ujian dan kecemasan sosial,ketakutan, kegagalan, kurang berprestasi dan dapat mengakibatkan hasil kesehatan mental yang merusak yang berakhir pada depresi dan kecemasan (Klassen, Krawchuk, \& Rajani, 2008)

Kemudian, penelitian yang dilakukan oleh Faruk (2011) mengemukakan bahwa prokrastinasi akademik dan motivasi akademik serta self-efficacy akademik menunjukkan korelasi terbalik yang signifikan antara prokrastinasi akademik dan prokrastinasi umum, tetapi tidak ada korelasi yang signifikan antara prokrastinasi akademik dan motivasi akademik dan efikasi diri akademik. Selain itu, kami menyimpulkan bahwa prokrastinasi umum dapat menjelaskan prokrastinasi akademik tetapi motivasi akademik dan self-efficacy akademik tidak memberikan kontribusi yang signifikan terhadap prokrastinasi akademik.

Kemudian, salah satu faktor penyebab prokrastinasi karena perkembangan teknologi adalah bermain game online. Berdasarkan penelitian yang dilakukan oleh Kurniawan (2017) Intensitas bermain game online memiliki pengaruh terhadap munculnya perilaku prokrastinasi akademik pada mahasiswa. Hal tersebut dapat ditunjukkan dengan semakin tinggi intensitas mahasiswa dalam bermain game online maka semakin tinggi pula kecenderungan mahasiswa untuk berperilaku prokrastinasi akademik. Hal ini ditandai dengan Hasil analisis regresi menunjukkan bahwa nilai signifikansi regression adalah sebesar 0,000. Mengacu pada kriteria hasil uji hipotesis menggunakan analisis regresi linier, maka nilai signifikansi $0,000<0,05$ sehingga $\mathrm{Ha}$ diterima dan Ho ditolak.

\section{LAYANAN PENGUASAAN KONTEN}

Layanan Bimbingan dan Konseling membantu Klien terutama Siswa dalam mengarahkan dirinya untuk menuju Kehidupan Efektif Sehari-Hari (KES). Bimbingan dan Konseling juga masuk kepada Sistem Integral Pendidikan itu sendiri. Dalam layanan Bimbingan dan Konseling terdapat 10 jenis layanan dimana salah satu layanan yang ada yaitu Layanan Penguasaan Konten. Layanan Penguasaan Konten merupakan layanan bantuan kepada Individu sendiri maupun dalam kelompok untuk menguasai kemampuan atau kompetensi tertentu melalui kegiatan belajar (Prayitno, 2004).

Senada dengan pendapat tersebut, Tohirin (2007) mengemukakan bahwa layanan penguasaan konten adalah suatu layanan bantuan kepada Individu (Siswa) baik sendiri 
maupun kelompok untuk menguasai kemampuan atau kompetensi tertentu dengan kegiatan belajar.

Konten yang dimaksud merupakan suatu keterampilan, kompetensi, ataupun kemampuan yang di dalamnya mengandung fakta dan juga berdasarkan data. Dengan diberikannya Layanan Penguasaan Konten ini, dapat membantu Siswa dalam menguasai aspek-aspek konten dengan baik.

Layanan Penguasaan Konten diberikan dalam bentuk Klasikal oleh Guru BK di Sekolah. Layanan ini diberikan denngan menggunakan metode, seperti metiode problem based learning, contextual teaching learning, dan juga menggunakan metode pelayanan lainnya.

Kemudian juga terdapat metode lain yaitu metode diskusi dan pemberian tugas yang dikemukakan oleh Sudjana (2009) bahwa metode diskusi dan juga pemberian tugas merupakan metode yang mampu merangsang anak untuk aktif belajar, baik secara individual, maupun secara berkelompok.

Pada pemberian layanan penguasaan konten juga memerlukan media dalam penyajian materi. Seperti media visual yaitu visualisasi pesan atau informasi yang disampaikan kepada Siswa melalui gambar, chart, grafik, ilustrasi, serta bagan (Arsyad, 2014). Kemudian ada juga media audio visual dengan menampilkan video dan didukung dengan perangkat audio (Munadi, 2008).

Dengan keterampilan tersebut, diharapkan Siswa dapat lebih mandiri dalam mengentaskan permasalahannya. Termasuk kepada Prokrastinasi Akademik. Layanan penguasaan Konten yang diberikan seperti kiat atau cara mengatur waktu mulai dari bangun tidur hingga tidur kembali sehingga Siswa dapat memiliki keterampilan terhadap hal tersebut.

Kemudian, penelitian yang dilakukan oleh Junita, Yuwono, \& Sugiharto (2014) menyatakan bahwa Terdapat perbedaan prokrastinasi akademik Siswa antara sebelum dan setelah mendapatkan layanan penguasaan konten. Hasil penelitian menunjukkan bahwa rata-rata prokrastinasi akademik setelah diberikan layanan penguasaan konten mengalami penurunan daripada sebelumnya. Hal ini menggambarkan bahwa dengan adanya layanan penguasaan konten yang diberikan pada siswa kelas VIII C SMP Negeri 3 Taman Kabupaten Pemalang berpengaruh terhadap tingkat prokrastinasi akademik siswa.

\section{KESIMPULAN}

Berdasarkan pembahasan yang telah dikemukakan, dapat simpulkan pembahasan tersebut sebagai berikut:

1. Prokrastinasi masih banyak dialami oleh Siswa di Sekolah.

2. Prokrastinasi merupakan masalah yang harus dientaskan terutama kepada Siswa.

3. Prokrastinasi terjadi akibat dari beberapa faktor seperti kecanduan dalam bermain game online, kemudian karena adanya keyakinan tidak rasional yang dimiliki oleh 
Siswa, Keyakinan tidak rasional tersebut dapat disebabkan oleh kesalahan dalam mempersepsikan tugas sekolah.

4. Prokrastinasi akademik dapat dikurangi dengan pemberian layanan penguasaan konten.

5. Pengurangan prokrastinasi akademik melalui pemberian layanan penguasaan konten yaitu dengan cara memberikan materi-materi layanan yang mengarah kepada keterampilan Siswa untuk mengatur dan membagi waktu dalam sehari. Siswa diberikan keterampilan untuk dapat mengatur waktunya dalam hal belajar dan seimbang dengan kegiatan lainnya ketika berada di lingkungan sekitarnya.

\section{REFERENSI}

Asyad, A. (2014). Media Pembelajaran. Jakarta: Rajawali Pers.

Balkis, M., \& Duru, E. 2009. "Prevalence of Academic Procrastination Behavior Among Pre-Service Teachers, and its Relationship with Demographics and Individual Preferences". Journal of Theory and Practices in Education, 5 (1): 18-32.

Basri, A. S. H. (2017). Prokrastinasi Akademik Mahasiswa Ditinjau Dari Religiusitas, 14(2).

Faruk, E. (2011). "Academic procrastination among undergraduates attending school of physical education and sports: Role of general procrastination, academic motivation and academic self-efficacy", 6(May), 447-455.

Fauziah, H. H. (2015). Faktor-Faktor Yang Mempengaruhi Prokrastinasi Akademik Pada Mahasiswa Fakultas Psikologi Uin Sunan Gunung Djati Bandung. Jurnal Ilmiah Psikologi, 2.2(105), 123-132.

Ghufron, M. N., \& Risnawita, R. (2010). Teori-Teori Psikologi. Yogyakarta: Ar Ruzz Media Group.

Gohil, E. (2014). "Procrastination and Self Esteem A Gender Based Study". Lecturer, Departmen of Psychology University of Jammu, Jammu and Kashmir". Global Journal of Interdisciplinary Social Sciences, 3 (3): 91-95.

Junita, E. D., Yuwono, D., \& Sugiharto, P. (2014). "Upaya Mengurangi Prokrastinasi Akademik Melalui Layanan Penguasaan Konten", 3(1), 17-23.

Klassen, R. M., Krawchuk, L. L., \& Rajani, S. (2008). "Academic procrastination of undergraduates: Low self-efficacy to self-regulate predicts higher levels of procrastination", 33, 915-931. https://doi.org/10.1016/j.cedpsych.2007.07.001

Kurniawan, D. E. (2017). “Pengaruh Intensitas Bermain Game Online Terhadap Perilaku Prokrastinasi Akademik Pada Mahasiswa Bimbingan Dan Konseling Universitas Pgri Yogyakarta", 3(1).

Munadi, Y. (2008). Media Pembelajaran. Jakarta: Gaung Persada.

Muyana, S., \& Dahlan, U. A. (2018). Prokrastinasi Akademik Dikalangan Mahasiswa Program Studi Bimbingan dan Konseling, 8(1), 45-52. https://doi.org/10.25273/counsellia.v8i1.1868 
Prayitno. (2004). Layanan Bimbingan dan Konseling. Padang: Universitas Negeri Padang.

Rumiani. (2006). "Prokrastinasi Akademik Ditinjau dari Motivasi Berprestasi dan Stres Mahasiswa". Jurnal Psikologi Universitas Diponegoro. Vol. 3, No. 2.

Sudjana. (2009). Dasar-Dasar Proses Belajar Mengajar. Bandung: Sinar Baru Algensindo.

Suharsono, F. S. dan Y. (2013). Self-Regulated Learning (SRL) Dengan Prokrastinasi Akademik Pada Siswa Akselerasi, 1(1),66-75.

Solomon, L. J., \& Rothblum, E. D. (1984). “Academic Procrastination: Frequency and Cognitive Behavioral Correlates". Journal of Counseling Psychology, 31 (4): 503-509.

Tohirin. (2007). Bimbingan dan Konseling di Sekolah dan Madrasah. Jakarta: Raja Grafindo Persada.

Undang-Undang Nomor 20 tahun 2003 tentang Sistem Pendidikan Nasional.

Winata, R. P. R. dan H. (2016). Prokrastinasi akademik menurunkan prestasi belajar siswa, $1,163-169$. 